ISSN 0206-5657. Вісник Львівського університету. Серія біологічна. 2018 Випуск 78. С. 14-19 Visnyk of the Lviv University. Series Biology. 2018. Issue 78. P. 14-19

\title{
CTAB VS. COLUMN-BASED DNA EXTRACTION FROM OLD HERBARIUM MATERIAL
}

\author{
J. Höpke, D. Albach \\ Carl von Ossietzky-University Oldenburg \\ 114, Ammerländer Heerstraße, Oldenburg D-26111, Germany \\ e-mail:dirk.albach@uni-oldenburg.de
}

\begin{abstract}
Herbarium specimens have become a major source of information in molecular research of biodiversity. However, getting good DNA samples from old herbarium specimens is still a challenge. The purpose of this project is to test different DNA extraction methods for old material from herbaria that often exhibit high DNA fragmentation. We compared a CTAB-based DNA extraction that is followed by a clean-up with paramagnetic beads with a modified NucleoSpin Plant II protocol, based on silica columns. Our results demonstrate that silica column-based methods have less problems with contamination by polysaccharide and polyphenolic compounds. Taking practical considerations into account, the columnbased method is better especially when trying to reduce the amount of leaf tissue used since handling with a tiny pellet makes CTAB difficult.
\end{abstract}

Keywords: CTAB, DNA extraction, herbarium DNA, paramagnetic beads, silica columns

\section{Introduction}

Research on natural biodiversity is often obscured by being forced "to work in suboptimal conditions that include inadequate preservation methods, limited sampling regimes, and suboptimal tissue type and quantity" (Blair et al., 2015, pp. 1079-1080). Nevertheless, it is possible to overcome the problem of inaccessibility of specimens by using herbarium material, which is a valuable source of DNA (Staats et al., 2011) to clarify a multitude of various questions. However, the bigger problem is that herbarium DNA is usually highly degraded (Staats et al., 2011) and that the low amount of DNA can be a limiting factor in downstream applications like high-throughput sequencing.

In our project aimed at investigations of the status of several "microspecies" of Veronica subg. Pseudolysimachium occurring in Eastern Ukraine, from where many taxa (often insufficiently understood or confusing) have been described (e.g., Klokov, 1976; Ostapko, 1994, 2014), we are restricted in our ability to collect new material, especially from Donetsk Oblast, Luhansk Oblast, and the Crimean Peninsula, due to the current political situation. Therefore, we must focus on herbarium material and, furthermore, we are interested to include type specimens and other original material to clarify the relationships of the described species.

In this study, we compared DNA extraction methods from two labs, the Jodrell Laboratory at the Royal Botanic Gardens Kew, UK, and the laboratory of Prof. Dr. Hanno Schäfer, Technical University Munich-Freising, Germany. Both labs have extensive experience in DNA extraction from herbarium specimens (e.g., Dodsworth, 2015; Schäfer et al., 2009; Dwivedi et al., 2018). The first mentioned lab uses a method with cetyltrimethyl ammonium bromide (CTAB), similar to the original CTAB protocol (Doyle and Doyle, 1990). The protocol was modified by subsequent cleaning with Solid Phase Reversible Immobilization beads (= SPRI), paramagnetic polystyrene beads coated with a layer of magnetite and carboxyl molecules, which can reversibly bind DNA in the presence of polyethylene glycol and salt (DeAngelis et al., 1995).

This method was compared with a silica column-based method, modified "NucleoSpin II Plant" mini DNA extraction protocol (Schäfer et al., 2009; Dwivedi et al., 2018). This standard (C) Höpke J., Albach D., 2018 
kit is especially interesting since it was already successfully used in a study to extract DNA from a Linnean type specimen (Chomicki and Renner, 2015).

\section{Material and Methods}

We tested those methods on 48 samples from Veronica subg. Pseudolysimachium. We took ca. $20 \mathrm{mg}$ from samples of our herbarium in Oldenburg (OLD) and from silica dried leaves. We included two specimens collected in the 1950s, two from the 1960s, nine from the 1970 s, one from the 1980s, five from the 1990s, ten from the 2000s, and ten from the last decade. Since the availability of old material from this subgenus was restricted, we supplemented this with other Veronica specimens as follows: two specimens from the 1950s, 11 from the 1970s, four from the 1980 s, and three from the 1990s.

For the CTAB mini protocol, 2x CTAB buffer was prepared as follows: $12.11 \mathrm{~g}$ powdery TRIS/TRIZMA (100 mM in the end), $7.5 \mathrm{~g}$ EDTA $(20 \mathrm{mM})$, filled up with distilled water to 0.51 and set to $\mathrm{pH}$ of 8.0. Afterwards $82 \mathrm{~g} \mathrm{NaCl}(1.4 \mathrm{M}), 20 \mathrm{~g} \mathrm{CTAB}(2 \% \mathrm{w} / \mathrm{v})$ and $20 \mathrm{~g} \mathrm{PVP}(2 \%$ $\mathrm{w} / \mathrm{v}$ ) were added and filled up with distilled water to $1: 1$. The lysis buffer contained $747 \mu \mathrm{l} 2 \mathrm{x}$ CTAB buffer with $3 \mu \mathrm{l}$ of 2-mercaptoethanol (equaling $0.4 \%$ of the isolation buffer) and $3 \mu \mathrm{l}$ of $10 \mathrm{mg} / \mathrm{ml} \mathrm{RNAse} \mathrm{A.} \mathrm{Each} \mathrm{sample} \mathrm{was} \mathrm{grinded} \mathrm{with} 250000 \mathrm{rpm}$ (revolutions per minute) for 2 min using a Retsch MM400 (Retsch Inc., Haan, Germany) and the freshly prepared lysis buffer added, afterwards incubated for $30 \mathrm{~min}$ in the water bath at $65^{\circ} \mathrm{C}$. Subsequently, $750 \mu 1$ SEVAG (= 24:1 chlorophorm:isoamyl alcohol) was added and the sample tubes shaken on an Orbital Shaker Model SO3 (Cole-Parmer Inc. Stone, United Kingdom), running with $250 \mathrm{rpm}$ for $30 \mathrm{~min}$. The samples were then centrifuged at $13000 \mathrm{rpm}$ for $15 \mathrm{~min}, 550 \mu \mathrm{l}$ supernatant mixed with $367 \mu \mathrm{l}-20{ }^{\circ} \mathrm{C}$ precooled isopropanol (=2/3 of the supernatant volume), and shortly centrifuged. Then the samples were twice centrifuged with $13000 \mathrm{rpm}$ for $15 \mathrm{~min}$ and washed by adding $750 \mu 170 \%$ ethanol. After drying, samples were incubated at $65^{\circ} \mathrm{C}$ in Qiagen AE elution buffer (Qiagen Inc., Venlo, Netherlands) for $30 \mathrm{~min}$ and again shortly centrifuged.

The bead clean-up was conducted by adding two times the eluted DNA volume $(=200 \mu \mathrm{l})$ of the undiluted AMPure XP bead solution (Beckman Coulter, Brea, CA, USA) to the eluted DNA, mixing and incubating at room temperature (RT) for $5 \mathrm{~min}$, placing the tubes in a 12tube magnetic separation rack for $1.5 \mathrm{ml}$ tubes (New England BioLabs Inc., MA, USA), waiting 5 min or longer until the solution becomes clear and a pellet formed, removing the clear solution, washed by adding $300 \mu \mathrm{l}$ of freshly prepared $80 \% \mathrm{EtOH}$, waiting $30 \mathrm{sec}$, removing the EtOH and repeating this washing step. Finally, the pellet was dried, $60 \mu \mathrm{l}$ AE elution buffer added, incubated for $5 \mathrm{~min}$ at RT each on a normal rack, then on a magnetic rack, and $50 \mu \mathrm{l}$ of the aqueous phase transferred to a new tube.

The dsDNA concentration was measured in a QuantiFlou dsDNA System (Promega Inc., Fitchburg, WI, USA). For calibration, a $2 \%$ standard:1xTE and a blank 1xTE with $100 \mu$ dye were used. $1 \%$ DNA samples were used for measuring. A260/A280 and A260/A230 absorbance ratios were measured in a Nanodrop 2000 (Thermo Fisher Scientific, Waltham, MA, USA) calibrated with Qiagen AE elution buffer (Qiagen Inc., Venlo, Netherlands).

For column-based DNA extraction, each sample $(10 \mathrm{mg}$ ) was grinded with 250,000 rpm for $20 \mathrm{sec}$ using a Retsch MM400 (Retsch Inc., Haan, Germany). The samples were then treated according to the NucleoSpin Plant II 'Mini' manufacturer's protocol (Macherey-Nagel, Düren, Germany) with SDS as the lysis buffer (using buffers PL2 and PL3) except for some small modifications: For the cell lysis, no RNAse was used and the incubation has been done at a slightly lower temperature $\left(62^{\circ} \mathrm{C}\right)$ with an increased incubation time $(40 \mathrm{~min})$ in a PHMT thermoshaker (Grant Instruments Inc., Cambridge, United Kingdom) at $500 \mathrm{rpm}$. For the clarification of the 
lysate, the centrifugation time was increased to $5 \mathrm{~min}$ and no filter column was used; instead, the clear supernatant was transferred to a $1.5 \mathrm{ml}$ tube and mixed with $350 \mu \mathrm{l}$ binding buffer before loading on the silica membrane. Furthermore, the centrifugation was also increased to $2 \mathrm{~min}$.

For column-based DNA extraction, a Qubit dsDNA HS assay kit with a dye/buffer premix was used (Thermo Fisher Scientific, Waltham, MA, USA) to measure the dsDNA concentration. For measuring the A260/A280 and A260/A230 absorbance ratios, an Epoch Microplate Spectrophotometer (BioTek Inc., Winooski, VT, USA) was used.

The parameter dsDNA concentration was multiplied with the final elution volume to get the total dsDNA yield and standardized by dividing with the used leaf dry mass to get an estimate of the afterwards so called "DNA yield" (in ng of DNA per $\mu$ l of used dried leaf tissue). For this parameter, as well as the absorbance ratios A260/A280 and A260/A230 (after removing 'not available data'), $\mathrm{AN}(\mathrm{C}) \mathrm{OVAs}$ were conducted to find relationships of the collection year and the extraction method. Here AN(C)OVA's were tested using a Shapiro test for normality and Lavene tests for assessing homoscedasticity assumptions (Dormann and Kühn, 2009). Even though these assumptions are often not met, AN(C)OVAS were used since they are mainly used for data inspection. Since the assumptions for normality and homoscedasticity were not met, we tested with Kuskal-Wallis rank-sum tests and the Dunn test that uses a Bonferroni p-value adjustment method as a posthoc test (Dunn, 1964). For pairwise comparisons we used t-tests and, if the assumptions were not met, a Wilcoxon rank sum test was conducted instead.

\section{Results}

The ANCOVA for DNA yield did not meet the statistical assumptions. Nevertheless, it indicated a difference between subgenera $(p=0.003)$. The ANCOVA for A260/A280 also did not meet the statistical assumptions (even after reducing the model to just significant variables) but it shows that the year of collection $(p=0.003)$ and DNA extraction method $(p<0.001)$ have an important influence. Here, although the ANCOVA has a low $\mathrm{R}_{2}$ value, the plot shows that the A260/ A280 ratio is increasing with the year of collection for both methods and that the column-based method is c. 0.1 above the CTAB-based method (Fig. 1). For the ANCOVA for A260/A230 the assumptions were also not fulfilled but it suggests that the extraction method $(p<0.001)$ is the only important variable.

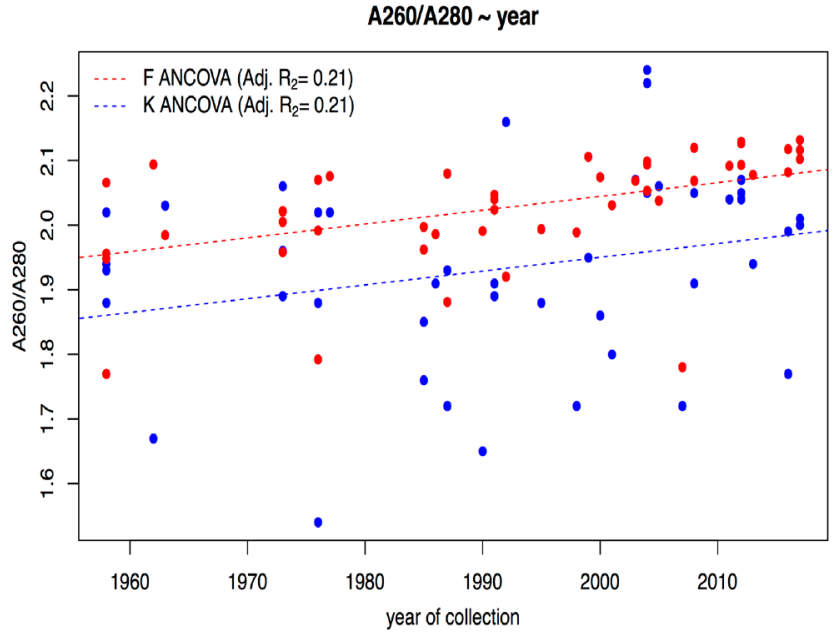

Fig. 1. ANCOVA result for A260/A280 against extraction method and year of collection as covariate (between $(\mathrm{K})$ for $\mathrm{CTAB}$ and $(\mathrm{F})$ for column-based) 
Comparing the DNA yield of both methods in a simple boxplot, while excluding outliers, and testing with a paired t-test, we see no significant difference $(\mathrm{p}=0.509)$. The CTAB-method has only a higher median value with 40.1 and some additional high "outliers" (above the whiskers that are defined with 1.5 times the interquartile range) whereas the column-based method has a median value of 33.5 (Fig. 2).

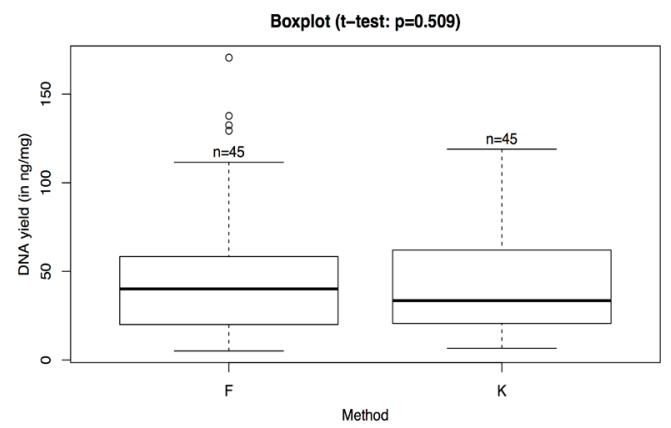

Fig. 2. Boxplot for DNA yield against extraction method (between (K) CTAB and (F) column-based extraction)

For comparing the absorbance ratios, the previously removed observations were not removed here since they had no special placement in their scatter plots. Comparing both methods for A260/A280 they were significantly different in a paired t-test. Here column-based extraction showed a higher median ratio with 2.04 than the CTAB method with 1.94. Also, the range of values for CTAB with 1.54 to 2.24 was much wider than for column-based extractions with 1.77 to 2.13 (Fig. 3).
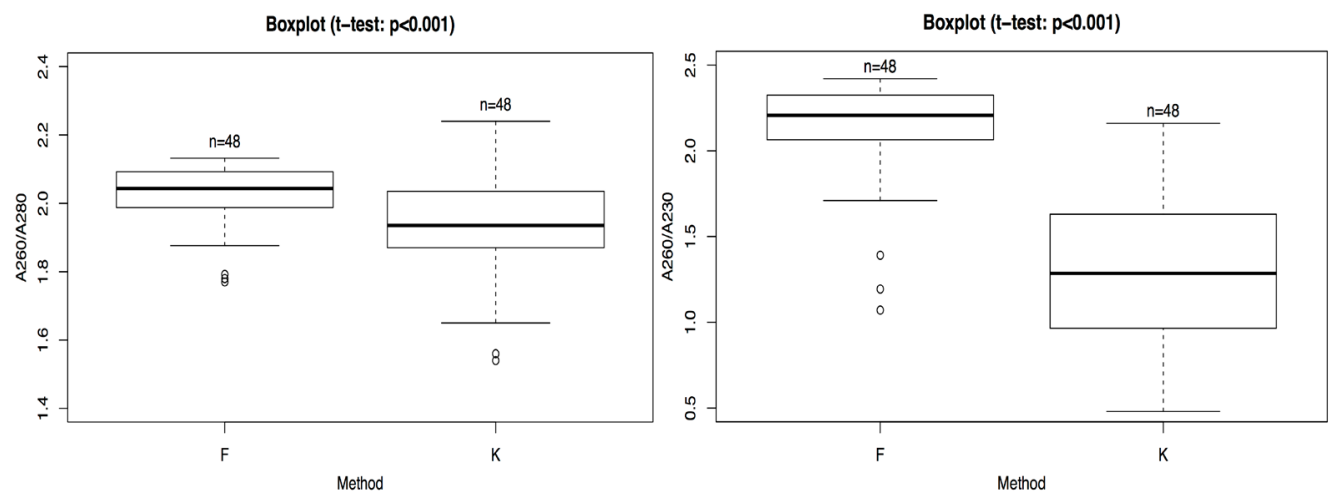

Fig. 3. Boxplot for A260/A280 (left) and A260/A230 (right) against extraction method (between (K) CTAB and (F) column-based extraction)

For A260/A230, a similar picture can be observed; although, the difference is more extreme (e.g., the median of column-based extraction is 2.21 and for CTAB just 1.29). This difference is also significant in a paired t-test ( $\mathrm{p}<0.001)$ (Fig. 3).

\section{Discussion}

As shown in the full sample set and subsample set, the DNA solutions from the columnbased DNA extraction method were much purer than those with the CTAB-based protocol, although we added an extra cleaning step with the magnetic beads. In the latter, the A260/A280 values were not markedly below 1.8 , thus indicating no contamination by proteins, phenols or other contaminants that absorb strongly near $280 \mathrm{~nm}$. However, the A260/A230 values were markedly 
below 2.0, which indicates a contamination with EDTA, carbohydrates and/or other phenols that absorb near $230 \mathrm{~nm}$ (Thermo Scientific, 2013). This corresponds to previous observations that polysaccharide and polyphenolic compounds can often not be removed in CTAB protocols (Turaki et al., 2017; Kenyon et al., 2008). This higher purity of column-based kits is supposed to be the result of more stringently washing since the DNA was captured by a glass fiber filter (OPS Diagnostics, 2018).

An important question when dealing with old type material is how to reduce the amount of tissue used, since $20 \mathrm{mg}$ leaf material may be highly destructive for small herbarium samples. Here, we made some important experiences handling $10 \mathrm{mg}$ of material instead of $20 \mathrm{mg}$ using the CTAB protocol. We experienced that the CTAB protocol becomes difficult to process with just c. $10 \mathrm{mg}$ of leaf tissue since the DNA pellet became too tiny and too shiny to see if a pellet formed at the side to the tubes. Therefore, we had to pipette several times up and down until we observed a pellet floating in the tube. Since all this increases the probability of losing the pellet, we propose to use (optimized) silica column-based DNA extraction methods instead.

\section{REFERENCES}

1. Blair C., Campbell C.R., Yoder A.D. Assessing the utility of whole genome amplified DNA for next-generation molecular ecology // Mol. Ecol. Res. 2015. Vol. 15. P. 1079-1090.

2. Carr S.M., Griffith O. M. Rapid isolation of animal mitochondrial DNA in a small fixed-angle rotor at ultrahigh speed // Biochem. Genet. 1987. Vol. 25. P. 385-390.

3. Chomicki G., Renner S.S. Watermelon origin solved with molecular phylogenetics including Linnaean material: another example of museomics // New Phytol. 2015. Vol. 205. P. 526-532.

4. DeAngelis M.M., Wang D.G., Hawkins T.L. Solid-phase reversible immobilization for the isolation of PCR products // Nuc. Acids Res. 1995. Vol. 23. P. 4742.

5. Dodsworth $S$. Genome skimming for next-generation biodiversity analysis // Trends Pl. Sci. 2015. Vol. 20. P. 525-527.

6. Dormann C.F., Kühn I. Angewandte Statistik für die biologischen Wissenschaften. Helmholtz Zentrum für Umweltforschung-UFZ 2, 2009, accessed 11 June 2018.

7. Doyle J., Doyle J. Isolation of plant DNA from fresh tissue // Focus. 1990. Vol. 12. P. 13-15.

8. Dunn O.J. Multiple comparisons using rank sums // Technometrics. 1964. Vol. 6. P. 241-252.

9. Dwivedi M., Barfield S., Pandey A., Schäfer H. Phylogeny of Zehneria (Cucurbitaceae) with special focus on Asia // Taxon. 2018. Vol. 67. P. 55-65.

10. Kenyon L., Lebas B., Seal S. Yams (Dioscorea spp.) from the South Pacific Islands contain many novel badnaviruses: implications for international movement of yam germplasm // Archives Virol. 2008. Vol. 153. P. 877-889.

11. Klokov M.V. De Veronicis spicatis // Nov. Sist. Vyss. i Nizsh. Rast. (Kiev). 1976. Vol. of 1975. P. 92-111. (In Russian, with Latin descriptions and diagnoses).

12. Knapp M., Clarke A. C., Horsburgh K. A., Matisoo-Smith E.A. Setting the stage-building and working in an ancient DNA laboratory // Ann. Anatom. Anz. 2012. Vol. 194. P. 3-6.

13. OPS Diagnostics. Isolation of Plant DNA using CTAB Protocol with a Spin Column. https:// opsdiagnostics.com/notes/protocols/spin_column_plant_protocol.html, 2018, accessed 12 June 2018.

14. Ostapko V.M. New species of Galium L. (Rubiaceae) and Veronica L. (Scrophulariaceae) from the south-east of Ukraine // Ukr. Bot. Zhurn. 1994. Vol. 51. P. 84-91. (In Ukrainian).

15. Ostapko V.M. New nomenclatural combinations and a new name in Pseudolysimachion (Plantaginaceae s.1. = Veronicaceae s. str.) and Phlomoides (Lamiaceae): taxa occurring in Ukraine // Ukr. Bot. Zhurn. 2014. Vol. 71. P. 673-675. 
16. Schäfer H., Heibl C., Renner S.S. Gourds afloat: a dated phylogeny reveals an Asian origin of the gourd family (Cucurbitaceae) and numerous oversea dispersal events // Proc. Royal Soc. London B: Biol. Sci. 2009. Vol. 276. P. 843-851.

17. Staats M., Cuenca A., Richardson J. E., Vrielink-van Ginkel R., Petersen G., et al. DNA damage in plant herbarium tissue // PLoS ONE 2011. Vol. 6. P. e28448.

18. Thermo Scientific (2013) 260/280 and 260/230 Ratios. T042-Technical Bulletin Nano Drop Spectrophotometers Rev. 2/09, http://www.nhm.ac.uk/content/dam/nhmwww/ our-science/ dpts-facilities-staff/Coreresearchlabs/nanodrop.pdf, accessed 20.04.2018

19. Turaki A., Ahmad B., Magaji U., Abdulrazak U., Yusuf B., et al. Optimised cetyltrimethylammonium bromide (CTAB) DNA extraction method of plant leaf with high polysaccharide and polyphenolic compounds for downstream reliable molecular analyses // African J. Biotech. 2017. Vol. 16. P. 1354-1365.

\title{
CTAB VERSUS COLUMN-BASED ЕКСТРАКЦІЯ ДНК ЗІ СТАРИХ ГЕРБАРНИХ ЗРАЗКІВ
}

\author{
Я. Хепке, Д. Альбах \\ Карл фон Осієцький університет Ольденбург \\ Аммерландська армійська дорога, 114, Ольденбург D-26111, Німеччина \\ e-mail:dirk.albach@uni-oldenburg.de
}

Гербарні зразки стали основним джерелом інформації під час молекулярних досліджень біорізноманіття, оскільки використання їх дає можливість подолати проблему недоступності зразків, необхідних для розв'язання безлічі різноманітних питань. Однак отримання хороших зразків ДНК старих гербарних зразків все ще $\epsilon$ складним завданням. Метою цього проекту було тестування різних способів вилучення ДНК зі старого гербарного матеріалу, в якому ДНК часто виявляється високофрагментованою. Було проведено порівняння методів вилучення ДНК із двох лабораторій: Лабораторії Джодрелла у Королівському ботанічному саду К'ю, Великобританія (де використовувався метод із цетилтриметиламоній бромідом - (СТАВ) за модифікованим протоколом шляхом подальшого очищення з твердофазними реверсивними іммобілізаційними кульками (= SPRI), парамагнітними полістироловими кульками, покритими шаром магнетиту, і карбоксильних молекул, які можуть зв'язувати ДНК за наявності поліетиленгліколю та солі), та лабораторії професора доктора Хано Шефера $з$ Технічного університету Мюнхен-Фрайзінг, Німеччина (де застосовувався метод, який базується на колонковому силікагелі за модифікованим протоколом міні ДНК екстракції «NucleoSpin II Plant»). Обидві лабораторії мають великий досвід у вилученні ДНК зразків гербарію. Наші результати свідчать, що під час застосування методів, які базуються на колонковому силікагелі, виникає менше проблем із забрудненням полісахаридами та поліфенольними сполуками. Враховуючи практичні міркування, методика на основі колонок краща, особливо якщо намагатися зменшити кількість використаної листкової тканини, оскільки обробка крихітних гранул робить застосування СТАВ складним.

Ключові слова: СТАВ, екстракція ДНК, парамагнітні кульки, колонковий силікагель, гербарій 